\title{
TREATMENT OF COMMON BILE DUCT DISEASES COMPLICATED BY OBSTRUCTIVE JAUNDICE (REVIEW)
}

\author{
Sochneva A. L.
}

\section{Kharkiv National Medical University}

\begin{abstract}
The article presents the up-to-date data concerning the treatment of common bile duct diseases complicated by obstructive jaundice. Nowadays, specialized clinics widely use mini-invasive interventions to treat this complicated pathology. Biliary tree decompression is the main objective of operative treatment. It is reasonable to perform antegrade and retrograde endobiliary interventions as preparatory and final stages of surgical treatment and in order to improve the patients' life quality and avoid hepatic impairment progression. Reconstructive-reparative operations following prior biliary decompression yield significantly better results as compared to surgical interventions without it.

Key words: common bile duct diseases, obstructive jaundice, antegrade interventions, retrograde interventions, reconstructive-reparative operations.
\end{abstract}

The issue of diagnosis and treatment of common bile duct diseases remains relevant due to the rapid growth of their prevalence among the population. In almost $95 \%$ of cases, they are accompanied by development of obstructive jaundice [1, p. 1004, 2, p. 68].

The causes of obstructive jaundice are benign and malignant diseases of hepato-pancreatobiliary organs [3, p. 757]. The literature points to the development of obstructive jaundice in 15$40 \%$ of patients with cholelithiasis and in the majority of patients with malignant bile duct neoplasms [4, p. 164].

Bile duct obstruction may be caused by choledocholithiasis as a complication of cholelithiasis and type I Mirizzi's syndrome compression of the common bile duct lumen by a concrement located in the gallbladder duct. During biliary colic fits, concrements are likely to migrate from the gallbladder to the common bile duct through the gallbladder duct [5, p. 56].

The main causes of obstructive jaundice in case of malignant neoplasms of hepatopancreato-biliary organs are as follows: pancreatic cancer $-47 \%$, bile duct cancer $-20 \%$, and major duodenal papilla and gallbladder cancer - around $15 \%[6$, p. 5,7, p. 6,8, p. 118$]$.

Corresponding Author:

Anastasia Sochneva, MD, PhD student,

Department of Surgery No.1.

Kharkiv National Medical University, Ukraine.

E-mail: sochnevanastya@gmail.com
Benign common bile duct neoplasms are rare, but they have a strong tendency to malignization. Literature describes their invasive growth and the tendency to local recurrence after isolated resections. As a rule, these diseases remain undiagnosed before the surgery or until the development of obstructive jaundice and cholangitis. Benign neoplasms mostly include granular cell tumors, adenomyomata, papillomata, and fibromata [9, p. 108].

Obstructive jaundice may not be accompanied by pain syndrome, but it may be manifested by the signs of cholangitis and hepatic impairment. It results in a large number of post-operative complications and the death rate reaches $15-30 \%$ [10, p. 172].

Dilation of bile ducts is an integral part of biliary hypertension. Hyperbilirubinemia develops as a consequence of increased serum bilirubin, which, in turn, is due to the penetration of bile components into blood. If serum bilirubin rises above $40 \mu$ mole/ 1 , clinical signs of obstructive jaundice become grossly visible [11, p. 47].

The main cause of lethal outcomes in obstructive jaundice is hepatic impairment. Irrespective of obstructive jaundice etiology, the course of hepatic impairment is similar in all patients. Hepatic impairment is enhanced by the following factors: tumor intoxication, cholangitis, hemorrhage, general anesthesia, surgery trauma. The grade and duration of hyperbilirubinemia directly influence the frequency and severity of post-operative complications. Serum bilirubin 
count above $200 \mu \mathrm{mole} / 1$ is considered hazardous, and the count of $400 \mu$ mole/l or more is critical for the development of hepatic impairment. Increased urea and serum creatinine is an unfavorable prognostic factor [12, p. 28].

Treatment outcomes depend directly on the severity of obstructive jaundice. Despite the rapid development of hepatobiliary surgery, there is no single classification of obstructive jaundice severity [13, p. 506].

Many researchers link the severity of obstructive jaundice to the baseline serum bilirubin. Thus, V. Fedorov et al. classify hyperbilirubinemia up to $100 \mu$ mole/ 1 as mild jaundice, 100-200 $\mu$ mole/l as moderate jaundice and above $200 \mu$ mole/1 as severe obstructive jaundice [14, p. 19]. Other authors use several signs to determine the severity of obstructive jaundice. Pitt H. A. found that 10 signs identified by him reliably correlated with the number of post-operative complications, and 5 with lethality, multiple organ failure, and bacteremia [14, p. 20]. Dixon J. M. et al. distinguished three independent factors that correlate with post-operative complications and lethality: hematocrit below 30\%, bilirubin over $200 \mu$ mole/1 and malignant etiology of obstructive jaundice [15, p. 846].

The proposed classifications and assessment scales are quite laborious, detailed and based on complex etiopathogenetic and morphofunctional data, which is hardly applicable in the clinical practice. The process of obstructive jaundice severity assessment should be based on clinical signs and generally accepted laboratory data that are easily applied in everyday surgical practice.

Simplicity of the severity assessment concept is illustrated in the Child-Pugh score, which is widely used in patients with liver cirrhosis. It has been recognized in the whole world and is the commonly accepted severity scale. Unfortunately, this scale is not applicable to the assessment of obstructive jaundice severity [16, p. 53, 17, p. 646].

Most authors believe that operations at the bilirubin level below $50 \mu$ mole/l do not involve any complications [18, p. 3140, 19, p. 475].

Development of morphological and functional changes in the liver is due to lasting cholestasis and biliary hypertension. The latter results in the development of hepatic impairment, purulent cholangitis and disseminated intravascular coagulation. The majority of patients are aged 60 and above. At this age, the main disease in many patients is accompanied by grave co-morbidity dictating the necessity of choosing the least traumatic tactics of surgical treatment $[20$, p. 18, 21$, p. 117,22 , p. 255,23 , p. 1170$]$.

Due to the active clinical implementation of mini-invasive interventions - endoscopic, X-ray $\mathrm{TV}$, laparoscopic, and their combinations, certain improvements have appeared in the treatment and diagnostic algorithm in patients with this grave pathology [24, p. 11, 25, p. 32].

In spite of the above, the issues of timely diagnosis and adequate treatment tactics in obstructive jaundice remain the most complicated ones in surgery of hepato-pancreato-biliary organs.

Endoscopic (retrograde) interventions remain the "golden standard" in the treatment of cholelithiasis complicated by choledocholithiasis. However, the question regarding the causes of endoscopic papillosphincterotomy failures remains unanswered. Such consequences of endoscopic papillosphincterotomy failures as reflux cholangitis and progressive hepatic impairment aggravate the patient's condition and necessitate reconstructive-reparative operations in the presence of obstructive jaundice and its direct complications $[26$, p. 59, 27, p. 26, 28, p. 49, 29, p. 77].

Endoscopic papillosphincterotomy involves a high surgical risk and a risk of such complications as acute pancreatitis, septic cholangitis, duodenal or common bile duct wall perforation. Literature indicates that complications following endoscopic papillosphincterotomy occur in 3-11\% of cases, and death rates reach $0.8-15.5 \%$. Anomalous position of bile ducts complicates the treatment and diagnostic measures. The final stage of retrograde endobiliary interventions is nasobiliary drainage with a thin catheter. Nasobiliary drainage significantly improves the effectiveness of endoscopic interventions and reduces the number of possible complications. Nasobiliary drainage is of great importance for such manipulations as stenting, treatment of external biliary fistula, cholangiogenic liver abscesses, bile aspiration for testing, and temporary bile duct drainage. Endoscopic papillosphincterotomy, and nasobiliary drainage up to separate bile duct stenting may be performed in patients with malignant bile duct pathology following endoscopic retrograde cholangiopancreatography [28, p. 50, 30, p. 70].

In addition to choledocholithiasis and common bile duct strictures, another grave disease of hepatobiliary organs is strictures of biliodigestive anastomoses of inflammatory origin. In nearly all cases, this pathology is a consequence of damaged bile ducts, their abnormal drainage, coarse surgical 
manipulations on ducts and lasting tumor invasion [10, p. 172, 13, p. 508].

Direct mini-invasive access to bile ducts can be ensured through antegrade endobiliary interventions. A number of patients with known unsuccessful or impossible endoscopic papillosphincterotomy due to technical or anatomic reasons underwent percutaneous transhepatic cholangiodrainage under X-ray or ultrasound control with the aim of bile duct decompression [31, p. 39].

Percutaneous transhepatic cholangiodrainage can ensure both external and internal-external drainage of bile ducts. Cholangiodrainage beyond the stricture area is possible immediately after percutaneous transhepatic cholangiodrainage. If single-time external-internal percutaneous transhepatic cholangiodrainage is impossible, it can be performed 7-10 days after external percutaneous transhepatic cholangiodrainage. External-internal cholangiodrainage is more physiological because it ensures bile flow to the digestive tract. Cholangiodrainage ends with measured decompression of bile ducts with subsequent final restoration of bile passage to the digestive system by surgical means [32, p. 852].

However, questions of the duration of bile duct decompression and optimal terms of a radical or palliative operation remain disputable. According to different literature sources, operation terms vary from 1-2 weeks after drainage to 4-6 weeks after serum bilirubin normalization. Such different opinions can be explained by the variability of biochemical blood test results in the presence of obstructive jaundice, which makes it difficult to assess the functional liver status based on individual results [33, p. 480, 34, p. 443, 35, p. 134].

Measured bile duct decompression for 4 28 hours with pressure drops in biliary ducts not more than $10 \mathrm{~mm} \mathrm{H}_{2} \mathrm{O}$ should be performed to prevent the fast decompression syndrome. When the pressure in the bile ducts falls to $160 \mathrm{~mm} \mathrm{H}_{2} \mathrm{O}$, it should be maintained at this level for another 24 hours. Measured bile duct decompression can be achieved by regulating the opening of the drainage catheter. External percutaneous transhepatic cholangiodrainage should be preferred in the presence of purulent cholangitis until full sanation of bile ducts and antibacterial therapy taking into account the associations of aerobic and anaerobic microflora. The following complications may develop following percutaneous transhepatic cholangiodrainage: migration of cholangiodrainage, bile outflow with the formation of bilomas, biliary peritonitis, hepatic impairment, etc. Complications were observed in $10-50 \%$ of patients with a lethality rate of $2.6-$ $16.6 \%$ [35, p. 33].

Lethality rates associated directly with percutaneous transhepatic cholangiodrainage are low at less than $5 \%$, and the prevailing number of lethal outcomes is due to general causes, especially hepatic impairment progression, and may reach $21.3 \%$. Intra-abdominal hemorrhage and hepatic impairment remain fatal complications of percutaneous transhepatic cholangiodrainage [36, p. 55, 37, p. 48, 38, p. 447].

The following factors should be taken into account when choosing the type of drainage intervention: bile duct obstruction level (proximal or distal), propagation of the pathological process on the surrounding organs and tissues, patient's condition (whether a radical surgery is planned after bile duct drainage), patient's life expectancy after mini-invasive intervention if a radical surgery is not indicated; likelihood of possible complications, material and technical resources, and the quality of performance of a given miniinvasive intervention.

The operative interventions aimed at eliminating the cause of military obstruction is chosen after obstructive jaundice has been resolved.

According to the authors' data, in the case of benign common bile duct diseases, $15-25 \%$ of operations take the form of stenting biliodigestive anastomoses. In the case of malignant hepatobiliary diseases, the number of such operations increases to $50-84 \%[39$, p. 39 , 40, p. 97].

Cancer of hepato-pancreato-biliary organs is an umbrella term encompassing malignant neoplasms of pancreas, major duodenal papilla and bile ducts. Due to the anatomic and topographic proximity and direct interaction of these organs, there are no differences in the clinical pattern of tumors in this localization. In the recent decades, there has been a rapid growth in the prevalence of hepatobiliary cancer and, as a consequence, mortality due to it in the whole world [41, p. 25].

Malignant hepatobiliary neoplasms account for $10-20 \%$ of digestive organ tumors and 6$10 \%$ of all cancers. The median age of patients is 60 years. Pancreatic cancer accounts for more than $50 \%$ of all hepatobiliary tumors. Around $30 \%$ of malignant tumors are found in the liver, bile duct and gallbladder. Tumors of the major duodenal papilla are observed in $15 \%$ of cases [42, p. 458]. 
Among malignant neoplasms, pancreatic cancer, gallbladder cancer and cholangiocarcinomas are the most common causes of strictures and stenoses.

Cholangiocarcinomas prevail among malignant neoplasms and are among the most complicated ones; they are an unsolved and still relevant problem of hepatobiliary surgery; they are the second most common among primary malignant liver neoplasms. They can develop at any point of bile ducts - from minor intrahepatic to distal common bile duct regions. Cholangiocarcinomas develop from the bile duct epithelium and are characterized by infiltrative growth along bile ducts and through their walls [43, p. 170, 44, p. 860].

The disease was first described by the pathohistologist Gerald Klatskin in 1965 in the American Journal of Medicine. He described 13 observations of a special form of malignant bile duct tumor process localized in the region of hepatic duct confluence. The disease was then named after him [45, p. 244].

The classification of cholangiocarcinomas proposed by Bismuth-Corlette is currently the most frequently used. It takes into account pathomorphological features of cholangiocarcinomas and frequent combination of intra and extrahepatic localization [46, p. 172].

The risk of cholangiocarcinomas increases by $15 \%$ in the case of such congenital and chronic bile duct diseases as Caroli disease, cysts, adenomata, multiple papillomatosis of the common bile duct, and biliodigestive anastomoses [47, p. 375].

According to the findings, it has been established that cholelithiasis does not increase the risk of cholangiocarcinoma development, which is opposite to gallbladder cancer [48, p. 1034].

The only way to address cholangiocarcinomas is surgical treatment. Resectability of the tumor process is not more than $10 \%[49$, p. 88].

The radicalism of the operative treatment can be achieved by extended resection of bile ducts and gallbladder, resection of the paracholedochal tissue and lymph nodes, and in some cases by extended liver and pancreato-duodenal resection [50, p. 107,51, p. 68].

It should not be forgotten that radical operations in the presence of obstructive jaundice are associated with numerous post-operative complications, and the death rate reaches 15$30 \%$ [52, p. 160], which is $3-4$ times higher as compared to operations following biliary decompression. Previously, the preparatory stage of radical treatment consisted in the deployment of biliodigestive anastomosis, whose type is determined by the level of bile duct blockage. Due to the implementation of mini-invasive interventions, such as percutaneous transhepatic cholangiodrainage and stenting, in the clinical practice, biliary decompression is not as traumatic as it used to be 20 years ago. However, the effectiveness of these two methods of biliary decompression prior to radical treatment remains an outstanding question. Also, the most disputable issues are the choice of the operation type depending on the localization and distribution of the tumor, as well as suitability of mini-invasive technologies as pre-operative preparation for a radical surgery [52, p. 160].

It is currently assumed that Bismuth-Corlette type III and type IV tumors are not a contraindication to radical operative treatment [22, p. 258].

Tumor invasion into hepatoduodenal ligament vessels is not a contraindication to resection. Portal vein resection ensures tumor-free resection and does not worsen the surgery outcome prognosis. On the contrary hepatic artery invasion worsens treatment results due to the perineural tumor extension $[50$, p. 112,52 , p. 20,53 , p. 37 , 54, p. 38,55, p. 12,56, p. 812].

Liver resections combined with total caudal lobectomy and resection of extrahepatic bile ducts are performed at the majority of leading hepatobiliary surgical centers. This practice ensures $70 \%$ resectability in cholangiocarcinomas $[57$, p. 451,58, p. 1494,59 , p. 331].

If cholangiocarcinoma is localized in distal regions of the common bile duct, an adequate extent of the operation was assumed to be pancreaticoduodenal resection. As a rule, radical operations involve more post-operative complications and higher lethality rates in spite of better direct outcomes of surgical treatment $[60$, p. 74$]$.

According to the literature, lethality after such interventions is up to $13 \%$ and complications are reported in $2 / 3$ of observations [56, p. 810, 61, p. 30].

Pre-operative preparation of patients for such major operative interventions is widely discusses in surgical communities. Murakami Y. et al. [62, p. 454] suggest performing biliary decompression on all patients with obstructive jaundice. This patient care tactics is followed by most Japanese hepatobiliary surgeons [61, p. 31].

The main reason for non-performance of radical surgical treatment is close proximity of 
vital organs and great vessels that are quickly involved in the tumor infiltrate.

If non-resectable cholangiocarcinoma and non-operable condition are diagnosed, percutaneous transhepatic cholangiodrainage should be chosen as the treatment method. External-internal percutaneous transhepatic cholangiodrainage of bile duct stenting should be done if possible. According to the literature, 50$90 \%$ of patients require stenting [47, p. 372].

Antegrade endobiliary interventions are justified in patients with established non-operability of the tumor process as biliodigestive anastomoses in the presence of tumor infiltration of the common bile duct and obstructive jaundice are associated with the risk of an increased number of post-operative complications and, as a consequence, lethal outcomes. Most surgical clinics have now abandoned the practice of performing bile duct-stenting operations in patients with diagnosed cholangiocarcinoma. However, the problem of assessing the effectiveness of biliary decompression methods remains unsolved. The most disputable issues are selection of the operation type depending on the localization and extent of the tumor, suitability of antegrade endobiliary interventions for this pathology, and their effectiveness as palliative treatment [63, p. 157].

It is now recognized that external-internal percutaneous transhepatic cholangiodrainage and bile duct stenting are preferable to external cholangiodrainage as it is more physiological. In the case of external-internal drainage, constant access to the ducts is preserved with bile passage to the duodenum [64, p. 2424].

However, not all literature sources agree that external-internal cholangiodrainage should be preferred. These authors consider its main drawback to be lack of adequate sanation of bile ducts and estimate of the excreted bile volume. In their opinion, developing cholangitis is a consequence of the reflux of intestinal contents into biliary tracts [65, p. 255].

The main advantages of percutaneous transhepatic cholangiodrainage as compared to traditional bile removal interventions include miniinvasiveness that leads to fewer contraindications, which is especially important in the case of cholemia, and absence of any special pre-operative preparation.

Struggle against complications associated with external and external-internal percutaneous transhepatic cholangiodrainage, decreased life quality of patients and loss of bile urged the development of a mini-invasive method of internal drainage - the endobiliary stenting.
Nitinol shape-memory stents are widely used metal endoprostheses. These stents automatically adjust to the set diameter after opening [66, p. 180].

Stents without the self-expansion feature are opened by the in-built balloon catheter blowing up after introduction. The main advantages of selfexpanding stents are their atraumaticity due to the small diameter of the delivery device and the stent's ability to assume the shape of the bile duct.

The emergence of nitinol stents with inner polyurethane or silicone coating increased its service life. Endoprostheses of this modification prevent the slotting or invasion of tumor or granular tissue into the stent cells. Comparative research of coated and uncoated stents in cholangiocarcinomas of distal bile duct sections demonstrated that the number of repeated procedures is lower in patients with coated stents [66, p. 181].

The most frequent complication following the deployment of coated stents is obturation of the cystic duct and the development of acute cholecystitis. The most severe complication associated with deployment of coated stents in the case of distal lesion of bile ducts is development of acute destructive pancreatitis due to the obturation of the pancreatic duct [67, p. 879].

The discussion related to the selection of methods for pancreatitis prophylaxis has been going on for a long time. It is assumed that prior endoscopic papillosphincterotomy is required for the prophylaxis of pancreatitis, but on the other hand it may result in the migration of the stent to the duodenal lumen [68, p. 449].

\section{Conclusion}

Antegrade endobiliary interventions in patients with benign common bile duct diseases, complicated by obstructive jaundice when it cannot be resolved by endoscopic means, had favorable effects on liver functioning, which is evidenced by clinical and laboratory data, in the first place by the total serum bilirubin count. Upon the analysis of treatment results, it can be noted that antegrade endobiliary interventions are not yet able to substitute endoscopic and traditional treatment of cholelithiasis complications, but they can be an alternative at the biliary decompression stage and can prepare the patient for a reconstructive-reparative operation and avoid the risk of post-operative complications.

Antegrade endobiliary interventions as a drainage treatment stage reduce the number of complications after the reconstructive-reparative treatment stage as compared to patients who 
underwent surgeries without prior biliary decompression.

Antegrade endobiliary interventions are an alternative method of surgical treatment of cholangiocarcinomas. They cannot substitute radical surgical treatment and just improve patients' quality of life and life expectancy. Antegrade interventions are justified both at the stage of preparation for a radical surgery if the tumor is resectable and as a final treatment method.

Despite the advantages, antegrade interventions involve the risk of complications, which accounts for the need for up-to-date equipment and sufficient medical experience to perform such interventions.

When choosing the method of drainage and the extent of the reconstructive-reparative operation, the level of localization of cholangiocarcinoma, its extension on adjacent organs and tissues and the patient's condition should be taken into account.

Prevention of complications following antegrade interventions should be done at all stages of clinical care. The most important are preventive measures taken right during the intervention and aimed to minimize the operational trauma and the risk of complications.

Endobiliary stenting has become an effective method of internal bile removal in patients with cholangiocarcinomas as a palliative treatment method.

\section{Conflict of interests}

There is no conflict of interests.

\section{References}

1. Williams, E.J., Green, J., Beckinham, I. et al. (2008). Guidelines on the management of common bile duct stones (CBDS). GUT. 57, 1004-1021.

2. Henson, D.E., Schwartz, A.M., Nsouli, H., \& Albores-Saavedra, J. (2009). Carcinomas of the pancreas, gallballader, extrahepatic bile ducts, and ampulla of vater share a field for carcinogenesis a population-based study. Arch. Pathol. Lab. Med, 133(1), 67-71. doi:10.1043/1543-2165-133.1.67.

3. Are, C., Gonen, M., D`Angelica, M., DeMatteo, R.P., Fong, Y., Blumgart, L.H., \& Jarnagin, W.R. (2006). Differential diagnosis of proximal biliary obstruction. Surgery, 243, 756-763.

4. Pomerantz, B.J. (2009). Biliary tract interventions. Tech. Vasc. Radiol., 12, 162-170.

5. Kotiv, B.N., Dzidzava, I.I., Smorodskiy, A.V. et al. (2013). Chirurgicheskaya taktika pri neopukholevoy mekhanicheskoy zheltukhe [Surgical tactics in non-tumor obstructive jaundice]. Topical issues of surgical hepatology: Congress materials, Donetsk, 110.

6. Shevchenko, Yu.L., Vetshev, P.S., Stoyko, Yu.M., Levchuk, A.L. et al. (2008). Diagnostika sindroma mekhanicheskoy zheltukhi [Diagnosis of obstructive jaundice syndrome]. Vestn. Natsyonalnogo mediko-khirurgicheskogo tsentra im. N.I. Pirogova, 3(2), 3-7.

7. Nychytailo, M.Yu., Zakharash, Yu.M., Ohorodnik, V.P., Zakharash, M.P. (2008). Diagnostychnolikuvalna taktyka z vykorystanniam miniinvazyvnych tekhnologii pry mekhanichnii zhovtianytsi, zumovlenii kholedokholitiazom [Diagnosis and treatment tactics using mini-invasive techniques in obstructive jaundice caused by choledocholithiasis]. Khirurgiya Ukrainy, 2(26), 5-11.

8. Kutsyk, Yu.B., Dovhanyk, Yu.I., Mikhel, Yu.M. et al. (2009). Etiologiia, patogenez, osoblyvosti khirurgichnoii taktyky u khvorykh z mekhanichnoiu zhovtianytseiu [Etiology, pathogenesis and surgical tactics in patients with obstructive jaundice]. Visn Ukr med stomat akademii, 9(1), 116-119.

9. Galperin, E.I., \& Vetshev, P.S. (Eds.). (2009). Rukovodstvo po khirurgii zhelchnych putey [Handbook of bile duct surgery] ( $2^{\text {nd }}$ ed.). M.: Vidar-M.

10. Nikfarjam, M., Staveley-O'Carroll, K.F., Kimchi, E.T., \& Hardacre, J.M. (2009). Pancreaticoduodenectomy in patients with a history of Roux-en Y gastric bypass surgery. JOP, 10, 169-173.

11. Galperin, E.I., Kotovskiy, A.E., \& Momunova, O.N. (2011). Optimalnyi uroven bilirubinemia pered vypolneniem operatsyi u bolnykh mekhanicheskoy zheltukhoy opukholevoy etiologii [Optimum bilirubinemia level before surgery in patients with obstructive jaundice of tumor etiology]. Ann. khir. hepatol., 1, 45-51;

12. Stoyko, Yu.M., Levchuk, A.L., Bardakov, V.G., \& Vetshev P.S. (2008). Vozmozhnosti sovremennykh metodov diagnostiki i obosnovanie lechebnoy taktiki pri mekhanicheskoy zheltukhe [Capabilities of modern diagnostic methods and justification of medical tactics in obstructive jaundice]. Vestnik khirurgicheskoy gastroenterologii, 2, 24-32.

13. Saidi, R.F., Elias, N., Ko, D.S., Kawai, Y.T., Markmann, J., Cosimi, A.B., \& Hertl, M. (2009). Biliary reconstruction and complications after living-donor liver transplantation. HPB (Oxford), 11, $505-509$. 
14. Galperin, E.I. (2011). Mekhanicheskaya zheltukha: sostoyanie "mnimoy stabilnosti", posledstviya "vtorogo udara", printsipy lecheniya [Obstructive jaundice: the state of "sham stability", consequences of the "second hit", treatment principles]. Ann. khir. hepatol., 16(3), 16-25.

15. Dixon, J.M., Armstrong, C.P., Duffy, S.W., \& Davies, G.C. (1983). Factors affecting morbidity and mortality after surgery for obstructive jaundice: A review of 373 patients. Gut, 24(9), 845-852.

16. Child, C.G., \& Turcotte, J.G. (1964). Surgery and portal hypertension. In: C.G. Child (Ed.), The liver and portal hypertension (50-64). Philadelphia: Saunders.

17. Pugh, R.N., Murray-Lyon, I.M., Dawson, J.L. et al. (1973). Transection of the oesophagus for bleeding oesophagal varices. Br. J. Surg., 60(8), 646-649.

18. Smith, R.A., Dajani, K., Dodd, S. et al. (2009). Preoperative Resolution of Jaundice Following Biliary Stenting Predicts More Favourable Early Survival in Resected Pancreatic Ductal Adenocarcinoma. Ann. Surg. Oncol., 15(11), 3138-3146.

19. Takahashi, T., Togo, S., Tanaka, K. et al. (2008). Safe and Permissible Limits of Hepatectomy in Obstructive Jaundice Patients. Wld J. Surg., 28, 475-481.

20. Galperin, E.I.,Akhaladze, G.G., \& Kotovsky, A.E. (2009). Patogenez v lechenii ostrogo gnoynogo kholangita [Pathogenesis in treatment of acute purulent cholangitis]. Annaly khirurgicheskoy gepatologii, 14(4), 13-21.

21. Kutsyk, Yu.B., Dovhanyk, Yu.I., Mikhel, Yu.M. et al. (2009). Etiologiia, patogenez, osoblyvosti khirurgichnoii taktyky u khvorykh z mekhanichnoiu zhovtianytseiu [Etiology, pathogenesis and surgical tactics in patients with obstructive jaundice]. Visn Ukr med stomat akademii, 9(1), 116-119.

22. Baton, O., Azoulay, D., Adam, D.V., \& Castaing, D. (2007). Major hepatectomy for hilar cholangicarcinoma type 3 and 4: prognostic factors and long-term outcomes. J Am Coll Surg, 204, 250-260.

23. Chen, X.P., Lau, W.Y., Huang, Z.Y., Zhang, Z.W., Chen, Y.F., Zhang, W.G., \& Qui F.Z. (2009). Extent of liver resection for hilar cholangicarcinoma. Br J Surg, 96, 1167-1175.

24. Shevchenko, Yu.L., Vetshev, P.S., Stoyko, Yu.M. et al. (2011). Prioritetnye napravleniya v lechenii bolnykh s mekhanicheskoy zheltukhoy [Priorities in treatment of patients with obstructive jaundice]. Annaly khirurgicheskoy gepatologii, 16(3), 9-16.

25. Avdosyev, Yu.V., Boyko, V.V., Abidov, E., \& Lavrenteva, O.Yu. (2013). Rentgenokhirurgicheskiye vmeshatelstva $v$ kompleksnom lechenii razlichnych zabolevaniy gepatopankreatoduodenalnoy zony, oslozhnennych mekhanicheskoy zheltukhoy [X-ray surgical interventions in integrated treatment of hepato-pancreato-duodenal diseases complicated by obstructive jaundice]. Kharkivska khirurgichna shkola, 2, 31-37.

26. Nichitaylo, M.Yu., Grubnik, V.V., Lurin, I.A. et al. (2013). Videoendoskopicheskaya diagnostika i minimalno invazivnaya khirurgiya kholedokholitiaza [Video endoscopic diagnosis and mini-invasive surgery of choledocholithiasis]. Kyiv: VSI "Meditsina".

27. Ohorodnyk, P.V., Kolomiytsev, V.I., Kushniruk, O.I. et al. (2013). Endoskopichne drenuvannia biliarnoii systemy pry hostrii obturatsii spilnoii zhovchnoii protoky [Endoscopic drainage of biliary system in acute obturation of the common bile duct]. Klinichna khirurgiia, 8, 24-29.

28. Istomin, N.P., Sultanov, S.A., \& Arkhipov, A.A. (2005). Dvukhetapnaya taktika lecheniya zhelchnokamennoy bolezni, oslzhnennoy kholedokholitiazom [Two-stage tactics of treating cholelithiasis complicated by choledocholithiasis]. Khirurgiya, 1, 48-50.

29. Alekseev, N.A., Snigirev, Yu.V., Taraskina, Ye.B. et al. (2012). Laparoskopicheskiye i minilaparotomnye operatsii v lechenii kholetsystokholedokholitiaza [Laparoscopic and minilaparotomic operations in the treatment of cholecystocholedocholithiasis]. Annaly khirurgicheskoy gepatologii, 17(3), $75-79$.

30. Balalykin, A.S, Gvozdik, V.V., Ulyanov, D.N. et al. (2006). O nereshennych problemach endoskopicheskoy chrespapillarnoy khirurgii kholangiolitiaza [On unsolved problems of endoscopic transpapillary surgery of cholangiolithiasis]. Annaly khirurgicheskoy gepatologii, 11(3), 70.

31. Kulezneva, Yu.V., Bruslik, S.V., Musaev, G.Kh. et al. (2011). Antegradnye metody dekompressii zhelchnych protokov: evolutsiya I spornye voprosy [Antegrade methods of bile duct decompression: evolution and controversial issues]. Annaly khirurgicheskoy gepatologii, 16, 35-43.

32. Shimizu, T., \& Yoshida, K. (1978). The rule of the serum bilirubin changes after biliary decompression in patients with severe jaundice. Hepatologica Jap, 19, 479-485. 
33. Mansfield, D.D., Sen, G., Oppong, K. et al. (2006). Increase in serum bilirubin levels in obstructive jaundice secondary to pancreatic and periampullary malignancy - implications for timiting of resectional surgery and use of biliary drainage. HPB, 8, 442-445.

34. Van der Gaag, N.A., Rauws, E.A., van Eijck, C.H. et al. (2010). Preoperative biliary drainage for cancer of the head of the pancreas. N. Engl. J. Med, 362(2), 129-137.

35. Zabazny, N.P., Zhuravlev, M.N., Groshev, I.A. et al. (2007). Otvedenie zhelchi pri vysokoy opukholevoy obturatsii vnepechenochnych zhelchnych putey [Removal of bile in high tumor obturation of extrahepatic bile ducts]. Rossiyskiy onkologicheskiy zhurnal, 4, 32-34.

36. Kanikovskyi, O.Ye., \& Kharchuk O.V. (2009). Etapna biliarna dekompresiia pry kholangiti ta mekhanichnii zhovtianytsi [Stagewise biliary decompression in cholangitis and obstructive jaundice]. Ukr. Zhurn. khirurgii, 1, 54-57.

37. Nychytaylo, M.E., Godlevskiy, A.I., \& Savoliuk, S.I. (2013). Vybor optimalnoy taktitki khirurgicheskogo lecheniya oslozhnennykh form neopukholevoy obturatsionnoy zheltukhi [Selection of the optimum tactics for the surgical treatment of complicated forms of non-tumor obstructive jaundice]. Topical issues of surgical hepatology: congress materials, Donetsk, 123.

38. Al-Bahrani, A.Z., Holt, A., \& Hamade, A.M. Acute pancreatitis in under-recognized risk of percutaneous transhepatic distal bile intervention. HPB, 8(6), 446-450.

39. Nychytaylo, M.E., Godlevskiy, A.I., \& Savoliuk, S.I. (2013). Prognozirovanie i otsenka otdalennykh rezultatov khirurgicheskoy korrektsyi neopukholevoy obturatsyonnoy zheltukhi [Prediction and assessment of distant outcomes of surgical correction of non-tumor obstructive jaundice]. Topical issues of surgical hepatology: congress materials, Donetsk, 124.

40. Siplivy, V.A., Beresnev, A.V., Grinchenko, S.V. et al. (2005). Khirurgicheskoye lecheniye proksimalnykh opukholey zhelchnych protokov [Surgical treatment of proximal bile duct tumors]. Kharkivska khirurgichna shklola, 2(1), 96-98.

41. American Joint Committee on Cancer. (2005). AJCC Cancer Staging. New York: Springer-Verlag.

42. Hirano, S., Kondo, S., Tanaka, E., Shichinohe, T., Tsuchikawa, T., Kato, K. et al. (2010). Outcome of surgical treatment of hilar cholangiocarcinoma: a special reference to postoperative morbididy and mortality. J Hepatobiliary Pancreat Sci., 17, 455-462.

43. Jane, I. Tsao, Yuji, Nimuta, Junichi, Kamiya et al. (2006). Management of Hilar Cholangicarcinoma: Comparsion of an American and Japanice Experience. Annals of Surgery, 232, 166-174.

44. Harmeet, M., \& Gregory, G. (2006). Cholangiocarcinoma modern advances in understanding a deadly old disease. J Hepatol, 45(6), 856-867.

45. Klatskin, G. (1965). Adenocarcinoma of the hepatic ducts at its bifurcation within the porta hepatic. Am J Med, 38, 241-256.

46. Bismuth, H., \& Corlette, M.B. (1975). Intrahepatic cholangioenteric anastomosis in carcinoma of the hilus of the liver. Surg. Gynecol. Obstet., 140, 170-178.

47. Kuang, D., Wang, G. (2010). Hilar cholangiocarcinoma: Pathology and tumor biology. Front. Med. China, 4, 371-377.

48. Kazuhiro, Otani, Kazuo, Chijiiwa, Masahiro, Kai et al. (2008). Outcome of Surgical Treatment of Hilar Cholangiocarcinoma. J Gastrointest Surg., 12, 1033-1040.

49. Kawasaki, S., Imamura, H., Kobayashi, A., Terumasa, N., Miwa, S., \& Miyagawa, S. (2003). Results of Surgical Resection for Patients With Hilar Bile Duct Cancer. Ann Surg, 238(1), 84-92.

50. Boyko, V. V., \& Maloshtan, A.V. (2008). Kliniko-anatomicheskoe obosnovanie radikal'nykh operatsii pri rake vnepechenochnykh zhelchnykh putei [Clinical-anatomic substantiation of radical surgery for cancer of the extrahepatic biliary tract] // Kharkovskaya khirurgicheskaya shkola, 4, 105-113.

51. Dotsenko, A.P., \& Zinchenko, E.I. (1977). Rak zhelchnogo puzyrya i vnepechenochnykh zhelchnykh putei [Cancer of the gallbladder and extrahepatic biliary tract]. M.: Meditsina.

52. Burnevich, E. (2004). Cholangiocarcinoma and carcinoma of the bile duct. Doctor, 11, 18-22.

53. Vishnevsky, V.A., Tarasyuk, T.I., \& Ikramov, R.Z. (2005). Radical surgery for cancer of the proximal bile duct. Annals of surgical hepatology, 10(3), 35-42.

54. Nazyrov, F.G., Ikramov, A.I., Akbar, M.M. et al. (2010). Diagnosis and tactics of surgical treatment of patients with tumors of the proximal bile duct. Surgery, 6, 36-39.

55. Shalimov, A.A., Kopchak, V.M., Dronov, A.I. et al. (2001). The clinic, diagnosis and treatment of tumors of the extrahepatic bile ducts. Clinical surgery, 6, 11-14. 
56. Neuhaus, P., Jonas, S., Bechstein, W.O., Lohmann, R., Radke, C., Kling, N. et al. (1999). Extended resections for hilar cholangiocarcinoma. Ann Surg, 230, 808-818.

57. Igami, T., Nishio, H., Ebata, T. et al. (2010). Surgical treatment of hilar cholangiocarcinoma: the "new era" the Nagoya University experience. J Hepatobiliary Pancreat Sci, 17, 449-454.

58. Nathan, H., Pawlik, T.M., Wolfgang, C.L. et al. (2007). Trends in survival after surgery for cholangiocarcinoma a 30-year population - based SEER database analysis. J Gastrointest Surg, 11, $1488-1496$.

59. Timm, S., Gassel, H.J., \& Thiede, A. (2007). Surgical therapy of proximal extrahepatic bile duct tumors (Klatskin tumors). Zentralbl Chir., 132, 328-335.

60. Seyama, Y., Kubota, K., Sano, K., Noie, T., Takayama, T., Kosuge, T. et al. (2003). Long-term outcome of extended hemihepatectomy for hilar bile duct cancer with no mortality and high survival rate. Ann Surg, 238, 73-78.

61. Nagino, M., Kamiya, J., Arai, T. et al. (2006). "Anatomic" right hepatic trisectionectomy (extended right hepatectomy) with caudate lobectomy for hilar cholangiocarcinoma. Ann Surg, 2006, 243, $28-32$.

62. Murakami, Y., Uemura, K., Sudo, T., Hashimoto, Y., Nakashima, A., Kondo, N., Sakabe, R., Ohge, H., \& Sueda T. (2011). Prognostic factors after surgical resection for intrahepatic, hilar and distal cholangiocarcinoma. Ann Surg Oncol, 18, 453-457.

63. Nimura, Y., Kamiya, J., Kondo, S. et al. (2000). Aggressive preoperative management and extended surgery for hilar cholangiocarcinoma: Nagoya experience. J. Hepatobiliary Pancreat. Surg., $7,155-162$.

64. Yoshida, H., Mamada Y., Taniai N. et al. (2006). One-step palliative treatment method for obstructive jaundice caused by unresectable malignancies by percutaneous transhepatic insertion of an expandable metallic stent. World J. Gastroenterol, 12(15), 2423-2426.

65. Borisova, N.A., Borisov, A.E., Kareev, A.V. (2003). Endobiliarnye metody korrektsii mekhanicheskoy zheltukhi [Endobiliary methods of obstructive jaundice correction]. In: A.E. Borisov (Ed.), Rukovodstvo po khirurgii pecheni i zhelchevyvodyashchich putey [Handbook of liver and bile duct surgery]. SPb: Skifiya, Vol. 2, 254-281.

66. Kaassis M., Boyer J., Dumas R. et al. (2003). Plastic or metal stent for malignant stricture of the common bile duct? Results of a randomized prospective study. Gastrointest. Endosc, 57, 178-182.

67. Suk, K.T., Kim, H.S., Kim, J.W. et al. (2006). Risk factors of cholecystitis after metal stent placement in malignant biliary obstruction. Gastrointest. Endosc., 4, 876-881.

68. Al-Bahrani, A.Z., Holt, A., Hamade, A.M. (2006). Acute pancreatitis in under-recognized risk of percutaneous transhepatic distal bile intervention. HPB, 8(6), 446-450.

Received: 14-Jan. - 2018

Accepted: 20-Apr. - 2018 